\title{
Bioleaching Coal Gangue with a Mixed Culture of Acidithiobacillus ferrooxidans and Acidithiobacillus thiooxidans
}

\author{
Zihao Chen ${ }^{1}{ }^{(}$, Xinying Huang ${ }^{1}$, Huan He ${ }^{1, *}$, Jielin Tang ${ }^{1}$, Xiuxiang Tao ${ }^{1}$, Huazhou Huang ${ }^{2}$, Rizwan Haider ${ }^{3}{ }^{\mathbb{D}}$, \\ Muhammad Ishtiaq Ali ${ }^{4}$, Asif Jamal ${ }^{4}$ and Zaixing Huang ${ }^{1,5, *}$
}

1 Key Laboratory of Coal Processing and Efficient Utilization of Ministry of Education, School of Chemical Engineering and Technology, China University of Mining and Technology, Xuzhou 221116, China; ts19040055a31@cumt.edu.cn (Z.C.); HXY19852125760@163.com (X.H.); c15396828196@163.com (J.T.); taoxx163@163.com (X.T.)

2 Key Laboratory of Coal Bed Methane Resource \& Reserving Process of the Ministry of Education, School of Resources and Geosciences, China University of Mining and Technology, Xuzhou 221008, China; huazhouh@163.com

3 Institute of Energy \& Environmental Engineering, University of the Punjab, Lahore 54590, Pakistan; rizwan.ieee@pu.edu.pk

4 Department of Microbiology, Quaid-i-Azam University, Islamabad 45320, Pakistan; ishimrl@qau.edu.pk (M.I.A.); asifjamal@qau.edu.pk (A.J.)

5 Department of Civil and Architectural Engineering, University of Wyoming, Laramie, WY 82072, USA

* Correspondence: hehuan6819@cumt.edu.cn (H.H.); zhuang@uwyo.edu (Z.H.); Tel.: +86-0516-83883194 (H.H.)

Citation: Chen, Z.; Huang, X.; He, H.; Tang, J.; Tao, X.; Huang, H.; Haider, R.; Ali, M.I.; Jamal, A.; Huang, Z. Bioleaching Coal Gangue with a Mixed Culture of Acidithiobacillus ferrooxidans and Acidithiobacillus thiooxidans. Minerals 2021, 11, 1043. https://doi.org/10.3390/min11101043

Academic Editor: Jean-François Blais

Received: 27 August 2021

Accepted: 23 September 2021

Published: 26 September 2021

Publisher's Note: MDPI stays neutral with regard to jurisdictional claims in published maps and institutional affiliations.

Copyright: (c) 2021 by the authors. Licensee MDPI, Basel, Switzerland. This article is an open access article distributed under the terms and conditions of the Creative Commons Attribution (CC BY) license (https:/ / creativecommons.org/licenses/by/ $4.0 /)$.

\begin{abstract}
A mixed culture of $A$. ferrooxidans and A. thiooxidans isolated from a coal gangue dump was used to bioleach coal gangue in a column reactor to investigate the leaching of elements. The changes of metal ions (Fe, Mn and $\mathrm{Cr}$ ) and sulfate in the leaching solution, elemental composition, mineral components and sulfur speciation of the coal gangue before and after bioleaching were analyzed by atomic absorption, anion chromatography, XRF, XRD and XPS. The results show that the mixed culture could promote the release of metal ions in coal gangue, with a leaching concentration of $\mathrm{Fe}>\mathrm{Mn}>\mathrm{Cr}$. EC and Eh have significantly increased with the increase of metal ion concentrations in the leaching solution. XRF analyses show that the contents of Fe, Mn and S decreased in coal gangue after bioleaching. XRD results suggest that the bioleaching has impacts on minerals in coal gangue, particularly the Fe-containing components. XPS analyses show that sulfur speciation in the raw gangue samples was associated with sulfate, dibenzothiophene and pyrite sulfur. After continuous leaching by the mixed culture, the total sulfur, pyrite sulfur and sulfate sulfur in coal gangue decreased from $2.06 \%$ to $1.18 \%, 0.66 \%$ to $0.14 \%$ and $1.02 \%$ to $0.52 \%$. The desulfurization rates of the pyrite and sulfate were $78.79 \%$ and $49.02 \%$. It is concluded that the mixed culture of these two microorganisms could effectively leach metals from coal gangue coupling with the oxidation of sulfide to sulfate. This study has provided fundamental information as a potential application in the recovery of valuable metals from coal gangue or environmental remediation related to gangue in the future.
\end{abstract}

Keywords: bioleaching; coal gangue; mixed culture; metals; sulfur speciation

\section{Introduction}

Coal mining and processing have generated massive coal gangue and accumulated as gangue dumps. The leaching, weathering and biological catalysis of coal gangue can release metals and sulfur into the environment. Furthermore, the formation of acid mine drainage (AMD) from oxidation of pyrites and other sulfur-bearing minerals in coal gangue causes serious environmental pollution to the air, surface water and surrounding soil $[1,2]$. There has been concerns over the pollution caused by coal gangue dumps. As such, the number of reports related to environmental pollution and risk assessment of sulfur and metals has increased in the past thirty years [3,4]. However, coal gangue also contains 
valuable elements and minerals, which can be used as a potential resource for recovery. Guo [5] had successfully produced $\mathrm{AlCl}_{3} \cdot 6 \mathrm{H}_{2} \mathrm{O}$ from an acid leaching liquor of coal gangue by using concentrated hydrochloric acid. Xiao [6] reported recovery of $\mathrm{Al}$ and Si from coal gangue by acid leaching with an elevated temperature. Zhang and Honaker [7] recovered rare earth elements and other critical metals $(\mathrm{Co}, \mathrm{Cr}, \mathrm{Li}, \mathrm{Mn}, \mathrm{Sr}$, and V) from calcination products of coal gangue by acid leaching and sequential chemical extraction. However, the study of metal leaching from coal gangue by microorganisms is limited [8].

It is well established that numerous microorganisms can inhabit around coal gangue dumps [9], among which sulfur-oxidizing bacteria (SOB) and ferrous oxidizing bacteria (FOB) are the most common ones. These bacteria have been used to remove sulfur and metals from coal gangue or coal because of their capability of increasing sulfur mobility by oxidation and dissolution of metal species [10]. Aytar [11] reported that the inorganic sulfur of coal was successfully removed by bioleaching of $A$. ferrivorans. Mishra [12] used a two-step sequential leaching method with Sinomonas flava $1 \mathrm{C}$ and $A$. ferrooxidans. It was found that the desulphurization was enhanced with a sulfur removal rate of 50 to $53 \%$. Studies also show that bio-desulfurization could be related to nutrients [13]. Chen [8] used A. ferrooxidans for the bioleaching of coal gangue and found that the liberation of iron, manganese and chromium increased. Sarswat [14] recovered rare earth elements from coal-based resources with a bioleaching approach. Furthermore, studies have shown that the mixed cultures of bacteria could effectively improve the bioleaching rate of valuable metals from metal sulfide [15-17]. In addition, studies also showed that a mixed culture of $\mathrm{SOB}$ and FOB can seemingly improve the removal of sulfur [18]. Oxidation and speciation of sulfur are the main biochemical processes in metal sulfide bioleaching. Liang [19] reported that the addition of sodium chloride could effectively reduce the accumulation of elemental sulfur during bioleaching of chalcopyrite by a thermophile Acidianus manzaensis. In one study, $\mathrm{S}^{0}$ deposited on the mineral surface was eliminated by the sulfur oxidation of A. ferrooxidans assisted by polyethylene glycol [20]. In another, $\mathrm{Fe}^{3+}$ and Sulfobacillus thermosulfidooxidans synergistically promoted $\mathrm{S}^{0}$ and $\mathrm{As}_{2} \mathrm{~S}_{3}$ removal during arsenopyrite bioleaching [21].

SOB and FOB have been found to accelerate metal leaching, sulfur oxidation rates of metal sulfide and bio-desulfurization of coal or coal gangue. All these suggest that the mixed cultures of bacteria could improve sulfur removal from coal gangue. However, the information about bioleaching of metal ions with mixed bacteria and sulfur oxidation in coal gangue remains unknown. In the present work, two microbial strains $A$. ferrooxidans SOB-1 (AF) and A. thiooxidans SOB-2 (AT), isolated previously, were employed in continuous leaching experiments of coal gangue. Metal ions and sulfate concentrations in the leaching process, the elemental concentrations, and the minerals and sulfur speciation before and after bioleaching were analyzed by atomic absorption, anion chromatography, XRF, XRD and XPS. The overall aim of the present study was to obtain information on the possibility of using coal gangue as a source for metal extraction with bacteria and investigation of bioleaching mechanisms. This could have an important ramification of extracting valuable metals from coal gangue using microbes.

\section{Materials and Methods}

\subsection{Microbes and Coal Gangue Sample}

A. ferrooxidans SOB-1(AF) (Accession number in Genbank: KR856280) and A. thiooxidans SOB-2 (AT) (Accession number in Genbank: KR856281) used in bioleaching experiments were isolated previously in our laboratory [22]. AF and AT were inoculated in 250-mL flasks containing 100-mL 9K medium and incubated at $30^{\circ} \mathrm{C}$ and $170 \mathrm{rpm}$ [13]. The initial density of the cells was $1.0 \times 10^{7}$ cells $/ \mathrm{mL}$. Bacterial cells were collected at the late exponential phase. The culture solution was filtered three times through a filter paper with pore sizes of 7-10 $\mu \mathrm{m}$ to remove any suspended solids. The filtrate was centrifuged at $10,000 \mathrm{rpm}$ for $15 \mathrm{~min}$. The pellet containing cells was washed thrice with diluted sulfuric acid $(0.1 \mathrm{~mol} / \mathrm{L})$ to remove trapped ions. 
The coal gangue sample was obtained from a coal gangue dump in Liejiaqiao coal mine $\left(43^{\circ} 69^{\prime} 65^{\prime \prime} \mathrm{N}, 112^{\circ} 43^{\prime} 47.66^{\prime \prime} \mathrm{E}\right)$ in Xiangtan, Hunan Province, China. The fresh coal gangue was crushed and sieved to various particle sizes for further usage.

\subsection{Bioleaching Experiment of Coal Gangue}

A column-type flow-through reactor was designed and fabricated to study the bioleaching of coal gangue [23]. As shown in Figure 1, the continuous leaching system was composed of a leaching column, a pump (DHL-A, Shanghai HuXi Analysis Instrument Factory Co., LTD, Shanghai, China), an electric stirring apparatus and a water bath. The leaching column was made from a PVC pipe with a dimension of $50 \mathrm{~cm}$ (length) and $9 \mathrm{~cm}$ (inner diameter). A supporting plate was fixed at the bottom of the column with a round hole of size $0.3 \sim 0.4 \mathrm{~mm}$ for draining. The column was packed with the coal gangue. The culture solution (10\% mixed bacteria in $9 \mathrm{~K}$ medium) or the sterile $9 \mathrm{~K}$ medium (as the control) was pumped continuously to the top of the column. The leachate was drained by gravity. A 2-L beaker was placed in a water bath at $30{ }^{\circ} \mathrm{C}$ for collecting the leaching solution. Both the column and beaker were covered to minimize contamination and water evaporation. Previously, it was determined that it was beneficial to use a mixed culture for sulfur oxidation [17]. In this work, the mixed culture was prepared at a ratio of 1:1 with AF and AT. For practical purposes, the column was packed with two layers of coal gangue with different particle sizes, i.e., the bottom layer with $0.3 \mathrm{~kg}$ had particle sizes between 8-10 $\mathrm{mm}$ and the top layer with $1 \mathrm{~kg}$ had particle sizes of $1-4 \mathrm{~mm}$. A volume of $1700 \mathrm{~mL}$ culture solution or medium solution was run through the column at a fixed flow rate of $10 \mathrm{~mL} / \mathrm{min}$ for 74 days. Sterile deionized water was added on a regular basis to make up the evaporation. The $\mathrm{pH}$, electronic conductivity (EC) and redox potential (Eh) were measured with a $\mathrm{pH}$ meter (PHS-3C, Leici, Shanghai, China), a conductivity meter (DDS-11A, Leici, Shanghai, China) and an ORP electrode (501, Lei-ci, Shanghai, China). An aliquot of $5 \mathrm{~mL}$ leaching solution was collected at an interval of four days to determine $\mathrm{pH}$, Eh and EC. Concentrations of $\mathrm{Fe}, \mathrm{Mn}$ and $\mathrm{Cr}$ were determined by atomic absorption spectrometry (TAS-986, General Analysis, Beijing, China) [24]. The concentration of $\mathrm{SO}_{4}{ }^{2-}$ was measured with ion chromatography (ICS-1500, Dionex, Sunnyvale, CA, USA). The correlation analysis among $\mathrm{pH}, \mathrm{Eh}, \mathrm{EC}, \mathrm{Fe}, \mathrm{Mn}, \mathrm{Cr}$ and sulfate were analyzed with SPSS Statistics 17.0 for Windows (SPSS Inc, Chicago, IL, USA). All the tests were run in triplicate. Mean values of the triplicate of the leaching experiments were presented.

\subsection{Sample Analyses}

By the end of the bioleaching, $50 \mathrm{~g}$ of coal gangue were collected from the column. The samples were washed 3 times with deionized water, vacuum freeze-dried for $10 \mathrm{~h}$ and ground to a particle size of $0.074 \mathrm{~mm}$ for further analyses. The total sulfur of raw, test and control gangue samples was analyzed according to the methods of China National Standards (GB/T 214-2007). The elemental contents, mineral components and sulfur speciation were investigated by XRF, XRD and XPS.

XRF: Elements of raw, test and control coal gangue samples were analyzed by XRF (Bruker Tiger $S_{8}$, Karlsruhe, Germany) using a rhodium target and $75 \mu \mathrm{m}$ Beryliumwindow with a high voltage power supply up to $4 \mathrm{kw}, 60 \mathrm{kV}$ and $170 \mathrm{~mA}$. It equips with three crystal changers (PET, XS-55 and LiF200) for different element analyses.

XRD: Main mineral components of raw, test and control coal gangue samples were analyzed by XRD (Bruker D8, Karlsruhe, Germany) with $\mathrm{Cu} \mathrm{K} \alpha$ radiation generated at $30 \mathrm{~mA}$ and $40 \mathrm{kV}$, operated at 0.02 two-theta steps from $3^{\circ}$ to $80^{\circ}$ and a count time of $0.02 \mathrm{~s}$ per step. 


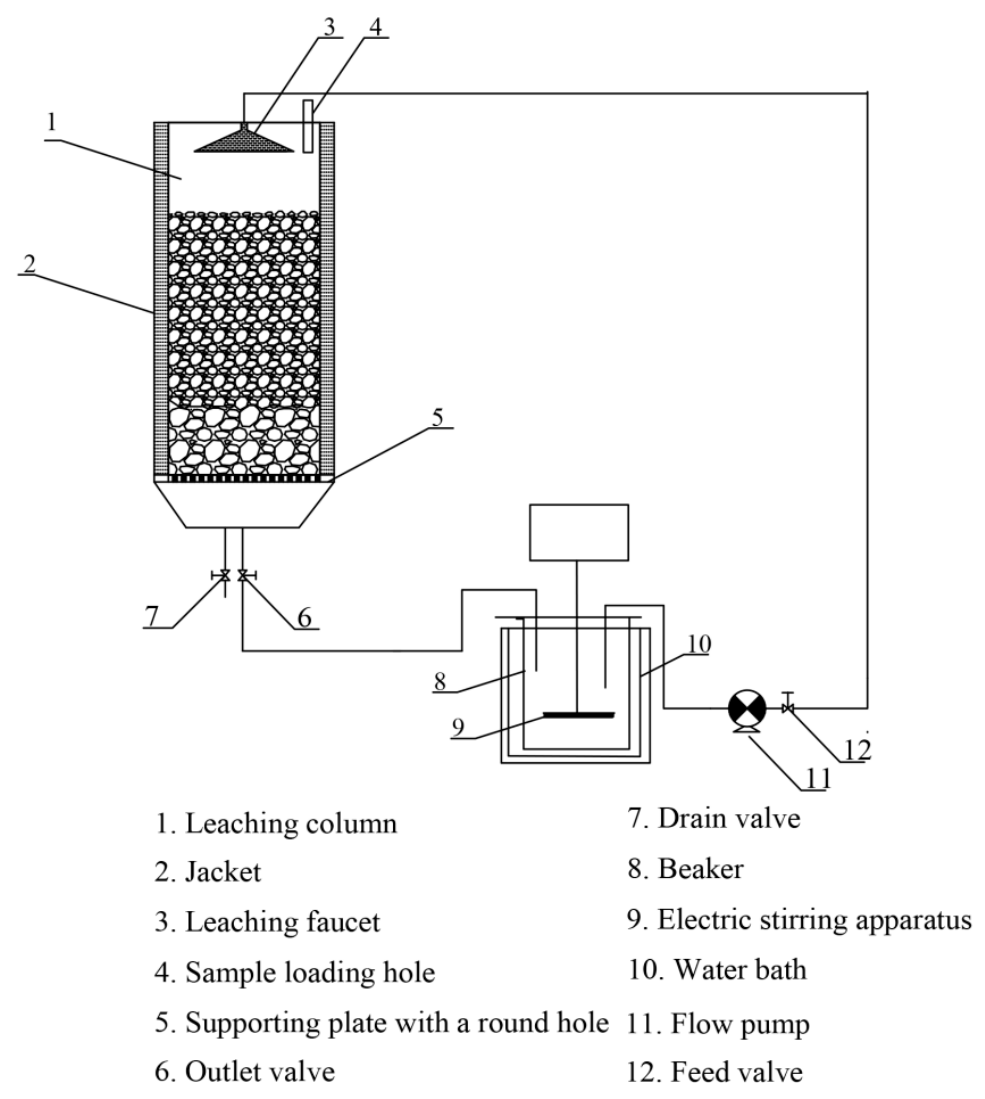

Figure 1. Column-type flow-through reactor.

XPS: Sulfur speciation analysis was conducted with XPS (Thermo Fisher ESCALAB250Xi, Waltham, MA, USA) equipped with an $\mathrm{Al} \mathrm{K \alpha}(1486.6 \mathrm{eV})$ source. The spectrometer was run with an analyzer pass energy of $20 \mathrm{eV}$ and $100 \mathrm{eV}$ for narrow scanning and wide scanning, corresponding to step energy of $0.05 \mathrm{eV}$ and $1 \mathrm{eV}$. The Shirley background was subtracted. The calibration for binding energy was carried out to the main C 1 s peak at $284.80 \mathrm{eV}$. The peak curves were resolved using Gaussian line shape with XPS peak 4.1 software. Concentrations of sulfur in various chemical speciation were calculated using the intensity of an appropriate line and XPS cross-sections. The relative contents of sulfur were calculated with total sulfur and relative peak areas.

\section{Results and Discussion}

\section{1. $p H$, Eh and EC Variation of Leaching Solutions}

The variations of $\mathrm{pH}$, Eh and EC of the leaching solutions are presented in Figure 2. As shown in Figure 2a, the $\mathrm{pH}$ values of the leaching solutions increased initially for both the control and test groups. They peaked at 3.22 and 2.77 on the 16th $\mathrm{d}$ and 12th $\mathrm{d}$ and then continuously declined to 2.35 and 2.0 by the end of the leaching experiment. The initial $\mathrm{pH}$ increase can be associated with the release of exchangeable alkali ions and soluble oxides in coal gangue [25]. In coal gangue leaching, dissolution and oxidation of acid-producing minerals (such as pyrite) is likely to result in the decline of $\mathrm{pH}$ [26]. The decrease of $\mathrm{pH}$ in the test group may also be related to the oxidization of sulfur compounds (such as pyrite), forming sulfuric acid by microbes [27]. A recent study showed that low $\mathrm{pH}$ environments could contribute to the release and migration of metal ions as well as dissolution rates [28]. In the control, the decrease of the $\mathrm{pH}$ is attributed to the equilibrium between coal and the medium (acidic $\mathrm{pH}$ at around 2.5). 

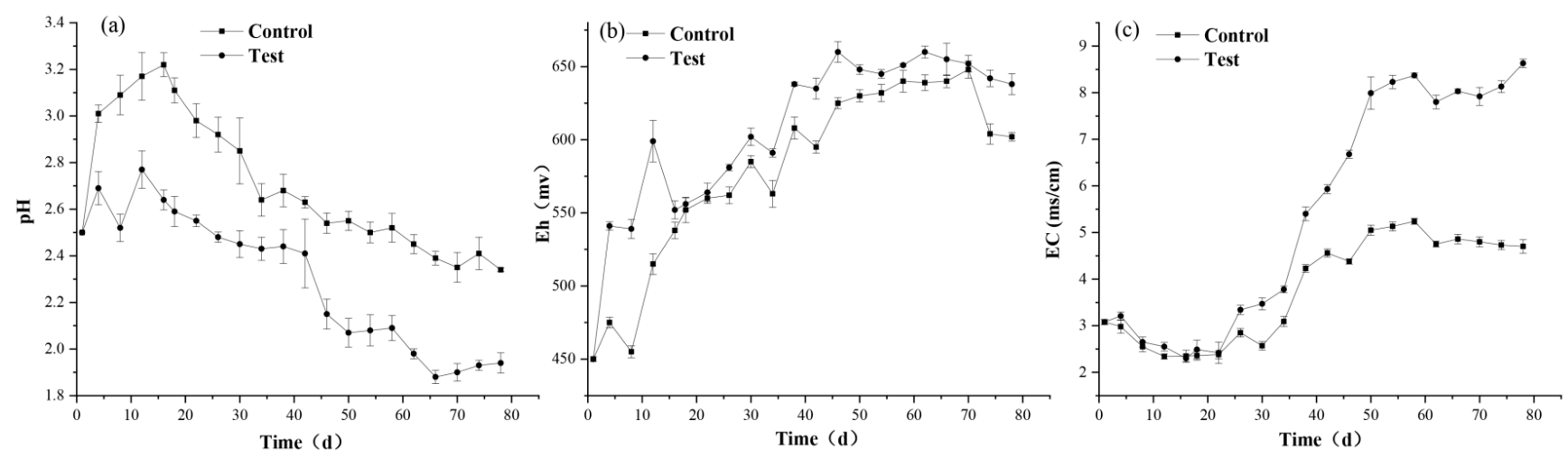

Figure 2. $\mathrm{pH}(\mathbf{a}), \mathrm{Eh}(\mathbf{b})$ and $\mathrm{EC}(\mathbf{c})$ of test and control groups in leaching solutions.

Eh variations of the leaching solutions are showed in Figure 2b. In general, the Eh increased over leaching time and reached a plateau with a maximum value of around $660 \mathrm{mV}$. The difference between the control group and the test group was insignificant. The test group exhibits slightly higher Eh than the control group. It is presumed that the concentration of substrates in coal gangue directly used by microbes was low and the chemical oxidation reaction had taken place in each group.

$\mathrm{EC}$ represents the total ionic concentration of the leaching solution. The EC variation of the leaching solutions is somehow correlated to $\mathrm{pH}$ values and presented in Figure 2c. Initially, the values for both control and test groups remained stable. After that (22 d), the values increased possibly because of the dissolution of the metal ions loosely bind to coal organics. In general, a lower $\mathrm{pH}$ has higher $\mathrm{EC}$, indicating that the metal and non-metal species can dissolve easily in mine water at very low $\mathrm{pH}$. After $50 \mathrm{~d}$, the increases were not obvious, possibly attributed to the fact that the metal ions were not available for leaching.

High acidity and EC in AMD water discharged from active, abandoned and reclaimed coal mine sites continues to be a global concern due to variable impacts on the quality of surface water and groundwater [29]. Dutta [30] studied the cytotoxicity of AMD in an Indian high-sulfur coal mining area and found mine water samples have high conductivity and high concentrations of trace elements which are detrimental to HepG2, A549, MIAPaCa2 and L6 cell lines. Although the cytotoxic effects to the environment were not investigated in this work, it is generally accepted that the discharge of water with extremely low $\mathrm{pH}(2.0)$ could impair soil quality and crop productivity.

\subsection{Metal Ions Concentrations}

As shown in Table 1, the main elements in raw coal gangue include $\mathrm{Al}, \mathrm{Fe}, \mathrm{Ti}, \mathrm{Mg}, \mathrm{Cr}$ and $\mathrm{Mn}$. These elements can be recycled and yet reduce the impacts on the environment. As shown in Figure 3, in general, the ion concentrations of $\mathrm{Fe}, \mathrm{Cr}$ and $\mathrm{Mn}$ increased with the leaching time. During 74 days of treatment, Fe concentration increased from 16.1 to $195.3 \mathrm{mg} / \mathrm{L}, \mathrm{Cr}$ from 2.2 to $137.1 \mathrm{mg} / \mathrm{L}$ and $\mathrm{Mn}$ from 9.6 to $92.7 \mathrm{mg} / \mathrm{L}$. In general, the release of metal ions is positively correlated to their concentrations in coal gangue which agrees with previous studies [2,31,32]. For the extraction of Fe, the leaching can be divided into four stages. Initially (1-18 d), the total Fe concentration in the leaching solution remained stable, then slowly increased in the second stage (18-42 d), rapidly increased in the third stage (42-54 d) and finally entered the stationary phase (54-74 d) (Figure 3a). In the control group, the same trend was observed except that the Fe concentration was lower, suggesting the oxidation of sulfur and iron speciation have an impact on the leaching of Fe $[33,34]$. In a natural environment, a coal gangue dump often experiences spontaneous combustion with pyrite oxidation via air and moisture as the main chemical reaction [35]. It is speculated that the leaching behavior of iron is related to the alternate speciation caused by air oxidation and microbial reduction. On the contrary, the leaching of $\mathrm{Cr}$ and $\mathrm{Mn}$ is more $\mathrm{pH}$-dependent as shown in Figure 3b,c. 
Table 1. Element analysis of raw and residual coal gangue by XRF.

\begin{tabular}{ccccccc}
\hline Element (\%) & $\mathbf{M g O}$ & $\mathbf{T i O}_{\mathbf{2}}$ & $\mathbf{A l}_{\mathbf{2}} \mathbf{O}_{\mathbf{3}}$ & $\mathbf{S i O}_{\mathbf{2}}$ & $\mathbf{C a O}$ & $\mathbf{F e}_{\mathbf{2}} \mathbf{O}_{\mathbf{3}}$ \\
\hline Raw & 0.23 & 0.27 & 5.81 & 37.80 & 0.45 & 2.13 \\
Control & 0.20 & 0.30 & 5.37 & 36.90 & 0.31 & 2.01 \\
Test & 0.18 & 0.27 & 5.29 & 36.30 & 0.15 & 1.56 \\
\hline Element $(\mathrm{mg} / \mathrm{kg})$ & $\mathrm{S}$ & $\mathrm{Cr}$ & $\mathrm{Mn}$ & $\mathrm{Cl}$ & $\mathrm{Pb}$ & $\mathrm{Sr}$ \\
\hline Raw & 2.05 & 74.95 & 131.62 & 0.026 & 0.001 & 0.045 \\
Control & 1.92 & 48.60 & 102.30 & 0.060 & 0.003 & 0.046 \\
Test & 1.66 & 12.30 & 53.24 & 0.075 & - & 0.010 \\
\hline
\end{tabular}

- No detected.
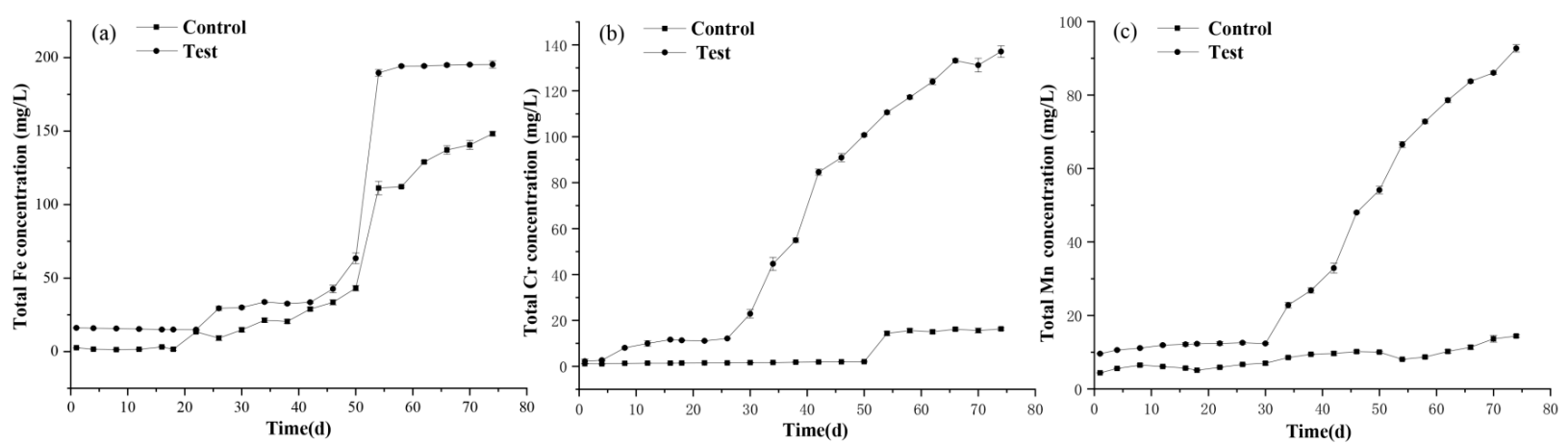

Figure 3. $\mathrm{Fe}(\mathbf{a}), \mathrm{Cr}(\mathbf{b})$ and $\mathrm{Mn}(\mathbf{c})$ concentrations in leaching solutions of test control groups.

The correlation of $\mathrm{pH}$ and ion concentrations was summarized in Table 2. The $\mathrm{pH}$ peaked at around day 16 and returned to initial $\mathrm{pH}$ at around day 30 , at which point the release rates of metal ions started to increase for $\mathrm{Cr}$ and $\mathrm{Mn}$ (Figures 2a and 3b,c). According to our previous work, the fraction of $\mathrm{Fe}$ and $\mathrm{Cr}$ in raw coal gangue was mainly residual fraction (residual fraction is the main form of occurrence of metal elements in coal gangue, its main mineral component is clay and its chemical composition is aluminosilicate), while the majority of Mn existed as iron manganese oxide bound fraction [8]. Different leaching behavior of $\mathrm{Fe}, \mathrm{Mn}$ and $\mathrm{Cr}$ was observed, suggesting the leaching mechanisms of the three metals are not the same. This may be related to the forms they are present in coal gangue [36,37].

Table 2. Correlation of $\mathrm{pH}, \mathrm{Eh}, \mathrm{EC}, \mathrm{Fe}, \mathrm{Mn}, \mathrm{Cr}$ and sulfate.

\begin{tabular}{ccccccccc}
\hline & Time & pH & Eh & EC & Fe & Cr & Mn $^{\text {SO }}{ }^{2-}$ \\
\hline Time & 1 & $-0.936^{* *}$ & $0.910^{* *}$ & $0.865^{* *}$ & $0.871^{* *}$ & $0.969^{* *}$ & $0.947^{* *}$ & $0.960^{* *}$ \\
$\mathrm{pH}$ & $-0.93^{* *}$ & 1 & $-0.795^{* *}$ & $-0.881^{* *}$ & $-0.889^{* *}$ & $-0.952^{* *}$ & $-0.957^{* *}$ & $-0.949^{* *}$ \\
$\mathrm{Eh}$ & $0.910^{* *}$ & $-0.795^{* *}$ & 1 & $0.781^{* *}$ & $0.701^{* *}$ & $0.849^{* *}$ & $0.780^{* *}$ & $0.796^{* *}$ \\
$\mathrm{EC}$ & $0.865^{* *}$ & $-0.881^{* *}$ & $0.781^{* *}$ & 1 & $0.794^{* *}$ & $0.938^{* *}$ & $0.883^{* *}$ & $0.825^{* *}$ \\
$\mathrm{Fe}$ & $0.871^{* *}$ & $-0.889^{* *}$ & $0.701^{* *}$ & $0.794^{* *}$ & $1^{* *}$ & $0.891^{* *}$ & $0.951^{* *}$ & $0.947^{* *}$ \\
$\mathrm{Cr}$ & $0.969^{* *}$ & $-0.952^{* *}$ & $0.849^{* *}$ & $0.938^{* *}$ & $0.891^{* *}$ & 1 & $0.975^{* *}$ & $0.954^{* *}$ \\
$\mathrm{Mn}$ & $0.947^{* *}$ & $-0.957^{* *}$ & $0.780^{* *}$ & $0.883^{* *}$ & $0.951^{* *}$ & $0.975^{* *}$ & $1^{* *}$ & $0.986^{* *}$ \\
$\mathrm{SO}_{4}{ }^{2-}$ & $0.960^{* *}$ & $-0.949^{* *}$ & $0.796^{* *}$ & $0.825^{* *}$ & $0.947^{* *}$ & $0.954^{* *}$ & $0.986^{* *}$ & 1 \\
\hline
\end{tabular}

Pearson correlation, correlation is significant at the 0.05 level (2-tailed). ${ }^{* *}$ Correlation is significant at the 0.01 level (2-tailed).

It is generally accepted that the metals in coal gangue could be released and pose a threat to the environment. In a study, the metals in coal gangue and their ecological risk were evaluated in Suncun coal mine. It was found that $\mathrm{Cr}$ and $\mathrm{Pb}$ have a strong effect on the ecological integrity of the environment [1]. In our previous work, soil properties, microbial flora and metal profiling surrounding the coal gangue dump were investigated. The study shows that the metals from the coal gangue dump did affect the surrounding 
environment [38]. Bioleaching and the recovery of metals with microbes offer an alternative way to tender this solid waste.

\subsection{Sulfate Concentration}

As shown in Figure 4, the $\mathrm{SO}_{4}{ }^{2-}$ concentration of the test group increased over time and is much higher than that of the control group. The $\mathrm{SO}_{4}{ }^{2-}$ concentration continued to increase over the entire period of the experimentation with a maximum concentration of $14.5 \mathrm{~g} / \mathrm{L}$. According to the results in Table 2, it shows that the dissolution of $\mathrm{SO}_{4}{ }^{2-}$ has a general significant correlation with the acidity of the leaching solution, and a highly significant correlation with Eh, EC and the concentrations of three metals. This suggests that the dissolution of $\mathrm{SO}_{4}{ }^{2-}$ is not exclusively dependent on the acidity of the culture solution. Bioleaching of pyrite follows the thiosulfate pathway. That is, the chemical bonds between sulfur and metal moieties are broken by iron (III) attack and liberate thiosulfate. Then, the free thiosulfate is oxidized to tetrathionate and other polythionates and finally to sulfate, while protons are also produced [32]. Because AF can oxidize both ferrous and reduced sulfur compounds while AT can utilize reduced sulfur compounds, the mixed culture plays an important role in promoting sulfide oxidation and hence sulfate leaching [39].

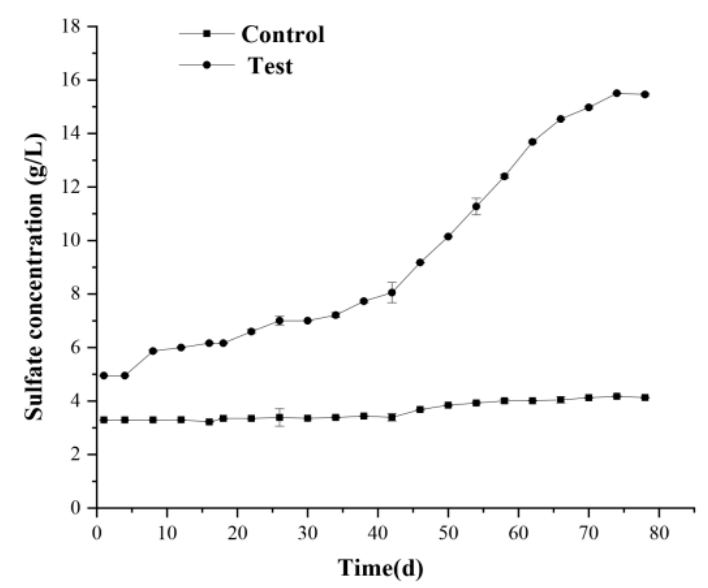

Figure 4. $\mathrm{SO}_{4}{ }^{2-}$ concentration in leaching solutions of test and control groups.

The high sulfate concentration in soil and water has become a prominent problem as it causes corrosion [40]. One study shows that the main damage of concrete lining was caused by sulfate in groundwater for 45 years [41]. It is obvious that high concentrations of sulfate can be generated by the mixed culture in the present work. The risk of damage to the facility of coal mines should be considered.

\subsection{Elemental Analysis of Coal Gangue before and after Leaching}

The main elements of the residual coal gangue after leaching are shown in Table 1. The concentrations of the test group for all the elements except for $\mathrm{Cl}$ were lower than the control group and raw coal gangue. The changes of elements $\mathrm{Fe}, \mathrm{Mn}, \mathrm{Cr}, \mathrm{Ca}, \mathrm{Sr}$ and $\mathrm{S}$ were more substantial than other elements, e.g., $\mathrm{Al}, \mathrm{Si}$, Ti and $\mathrm{Mg}$. The concentrations of Fe, Mn and $\mathrm{Cr}$ of the test group were obviously lower than that of the control group. This agrees with the analyses in the leaching solutions in that the concentrations of $\mathrm{Mn}, \mathrm{Cr}$ and $\mathrm{SO}_{4}{ }^{2-}$ increased with the leaching time (Figures 3 and 4). The results suggest that sulfide sulfur in the coal gangue was oxidized by the microorganisms, forming mainly $\mathrm{SO}_{4}{ }^{2-}$. In addition, the bioleaching has significantly improved the release of metal ions from coal gangue. The significant correlation between metal ions and sulfate illustrates that the leaching is mainly related to sulfide oxidation. 


\subsection{Mineral Components Analysis before and after Leaching}

Figure 5 shows the mineral components of raw and residual coal gangue after leaching. Quartz, kaolinite and pyrite were detected in all three samples. According to the XRF analysis in Table 1, Fe, Si and $\mathrm{Al}$ are the main elements in coal gangue, which are also the main elements of these minerals. In the raw gangue, iron-containing minerals including pyrite, hematite and siderite, and other peaks representing calcite and titanic schorl were detected (Figure 5a). However, after leaching, the diffraction peaks of hematite, siderite, calcite and titanic schorl in the test group (Figure 5b) and control group (Figure 5c) were not detectable. Hematite and siderite are more readily soluble in acidic conditions, whereas the solubilization of pyrite involves oxidation. It is assumed that $\mathrm{Ca}$ and $\mathrm{Ti}$ in the minerals were solubilized although they were not analyzed. With $\mathrm{CaCO}_{3}$ as its main component, calcite can be dissolved in acid solutions, while acid leaching is also a conventional technique for the recovery of titanium from ores [42]. However, the total concentration of Ti remained unchanged after bioleaching (Table 1), suggesting that there may be other major forms of Ti-containing constituents that are not accessible to bioleaching. On the other hand, several novel crystal diffraction peaks were detected in the test and control samples, indicating that the leaching process may provide a chemical environment not only for ore dissolution but also for the production of derivatives or new crystal structures.
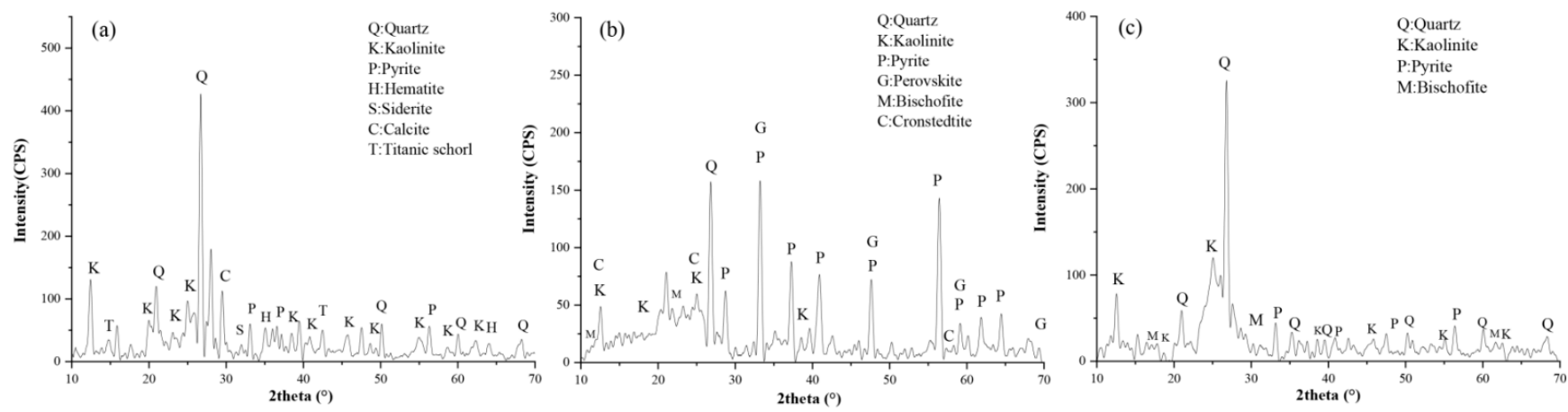

Figure 5. Mineral composition of raw coal gangue (a), test group (b) and control group (c).

\subsection{Desulfurization and Sulfur Speciation Analysis}

The total sulfur in coal gangue samples were $2.06 \%$ (raw gangue), $1.06 \%$ (control) and $1.18 \%$ (test group), suggesting the mixed culture has enhanced the sulfur removal. XPS as a non-destructive method has been widely used in qualitative analysis, semiquantitative analysis and quantitative analysis of sulfur in coal [43]. The peak fitting of the XPS analysis of the coal gangue samples is shown in Figure 6 and Table 3. The binding energy of different sulfur species is assigned to pyrite and mercaptan (162.1-163.6 eV), thiophene (164.0-164.4 eV), sulfoxides (165.0-166.0 eV), sulfone (167.0-168.3 eV) and sulfate $(>168.4 \mathrm{eV})[44,45]$. As shown in Figure 6a, the raw gangue had peaks at the binding energy of $164.2 \mathrm{eV}, 165.3 \mathrm{eV}$ and $169 \mathrm{eV}$, corresponding to pyrite, dibenzothiophene (DBT) and sulfate. As shown in Table 3, sulfate accounts for about half of the peak area of sulfur with a relative content of $1.02 \%$. The relative content of pyrite and DBT are $0.66 \%$ and $0.38 \%$. Pyrite content in the test group decreased from $0.66 \%$ to $0.14 \%$ with a desulfurization rate of $78.79 \%$, whereas it remained unchanged in the control group, suggesting the dissolution of pyrite was attributed to bacteria oxidation. SOB and FOB have a special enzyme system that could enhance the oxidation of pyrite $[46,47]$. Under the action of microbial oxidation, sulfur is converted into sulfates and hence improved the desulfurization of gangue [48]. On the contrary, for sulfate, the control group (from $1.02 \%$ to $0.38 \%$, or $62.75 \%$ ) had a higher dissolution rate than that of the test group (from $1.02 \%$ to $0.52 \%$, or $49.02 \%$ ). This suggests that the sulfur speciation induced by the biological processes is complicated and needs further analysis. It can be speculated that the increase of sulfate concentration in the leaching solution of the test group is mainly attributed to the oxidation of pyrite by 
the microorganisms. Sulfate originated from pyrite oxidation could be retained in the coal gangue matrix and explains the higher leaching rate of sulfate in the control group. Relative content of DBT in the coal gangue increased from $0.38 \%$ (raw) to $0.52 \%$ (test). It is speculated the organic moieties such as sulfhydryl and glutathione groups may be produced by SOB that contains similar functional groups in DBT.
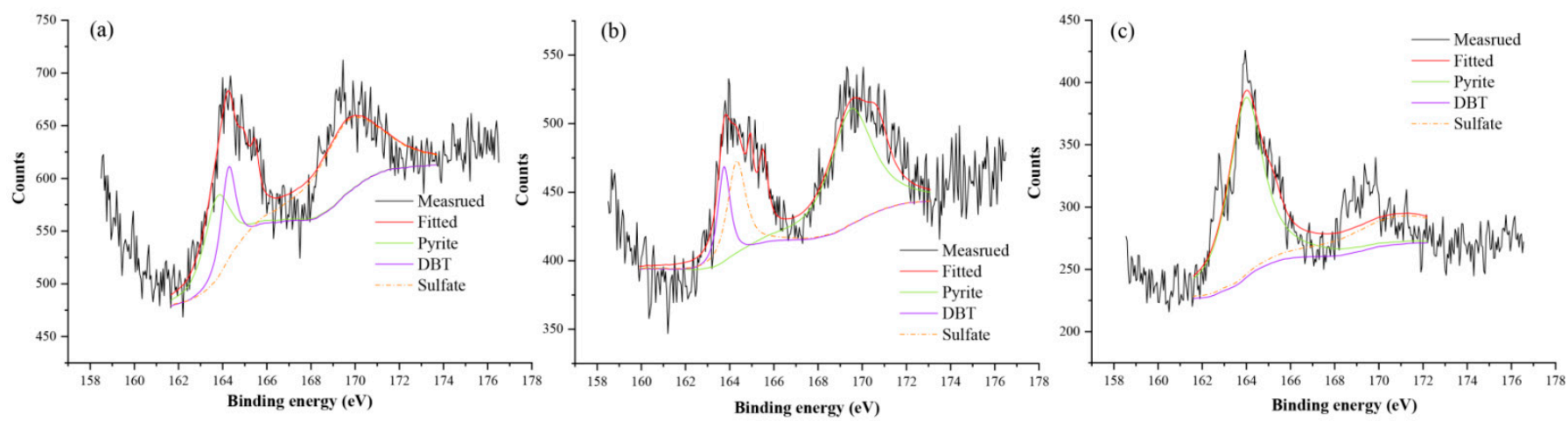

Figure 6. XPS peak fitting of raw coal gangue (a), test group (b) and control group (c).

Table 3. Sulfur speciation in raw, test and control gangue samples.

\begin{tabular}{ccccccc}
\hline \multirow{2}{*}{$\begin{array}{c}\text { Sulfur } \\
\text { Speciation }\end{array}$} & Peak Areas \% & $\begin{array}{c}\text { Relative } \\
\text { Contents \% }\end{array}$ & Peak Areas \% & $\begin{array}{c}\text { Relative } \\
\text { Contents \% }\end{array}$ & Peak Areas \% & $\begin{array}{c}\text { Relative } \\
\text { Contents \% }\end{array}$ \\
\cline { 2 - 7 } & 31.88 & 0.66 & 11.75 & 0.14 & 45.95 & 0.63 \\
Pyrite & 18.62 & 0.38 & 44.25 & 0.52 & 12.90 & 0.05 \\
DBT & 49.49 & 1.02 & 43.99 & 0.52 & 41.14 & 0.38 \\
Sulfate & & & & & & \\
\hline
\end{tabular}

\section{Conclusions}

Continuous bioleaching of metals in coal gangue was studied in a column reactor with a mixed culture of $A$. ferrooxidans SOB-1 and A. thiooxidans SOB-2. The present results demonstrate that the extraction of metal ions including $\mathrm{Fe}, \mathrm{Mn}$ and $\mathrm{Cr}$ can be significantly enhanced by bioleaching processes. The leaching of metal ions has a strong relationship with $\mathrm{pH}$ and sulfate in the leaching solution. The release of Fe was mainly caused by the oxidation of pyrite. The main minerals in the coal gangue are pyrite, quartz and kaolinite. The leaching of Fe is attributed to the oxidation of iron sulfide by the microorganisms, while $\mathrm{Mn}$ and $\mathrm{Cr}$ are more dependent on the acidic conditions. The mixed culture has obviously improved sulfur removal from coal gangue with a reduction of total sulfur from $2.06 \%$ to $1.18 \%$. Pyrite sulfur in coal gangue decreased from $0.66 \%$ to $0.14 \%(78.79 \%)$ which is also mainly attributed to bacterial oxidation. The present work implies that the valuable metals in coal gangue can be extracted with SOB and FOB. This also provides a potential application technique to the recovery of valuable metals from coal gangue or environmental remediation related to gangue in the future.

Author Contributions: Conceptualization, H.H. (Huan He); methodology, Z.C.; software, J.T.; validation, Z.C., X.H. and J.T.; formal analysis, H.H. (Huan He); investigation, X.H.; resources, X.T.; data curation, X.H.; writing-original draft preparation, Z.C.; writing—review and editing, H.H. (Huan He), R.H., M.I.A., A.J. and Z.H.; visualization, Z.C.; supervision, Z.H. and H.H. (Huazhou Huang); project administration, H.H. (Huan He); funding acquisition, H.H. (Huan He) and Z.H. All authors have read and agreed to the published version of the manuscript.

Funding: This research was funded by the Fundamental Research Funds for the Central Universities, grant number 2021ZDPY0210.

Data Availability Statement: The data supporting the findings of this study are available within the article. 
Acknowledgments: We greatly appreciate the help of Hengxi Tong and Fan Chen during field work. We are grateful to Shangming Zhao for the help with the laboratory analyses.

Conflicts of Interest: The authors declare no conflict of interest. The funders had no role in the design of the study; in the collection, analyses, or interpretation of data; in the writing of the manuscript, or in the decision to publish the results.

\section{References}

1. Hua, C.Y.; Zhou, G.Z.; Yin, X.; Wang, C.Z.; Chi, B.; Cao, Y.Y.; Wang, Y.; Zheng, Y.; Cheng, Z.R.; Li, R.Y. Assessment of heavy metal in coal gangue: Distribution, leaching characteristic and potential ecological risk. Environ. Sci. Pollut. Res. Int. 2018, 25, 32321-32331. [CrossRef]

2. Li, C.; Zheng, L.G.; Jiang, C.L.; Ding, S.S. Characteristics of leaching of heavy metals from low-sulfur coal gangue under different conditions. Int. J. Coal Sci. Technol. 2021, 8, 780-789. [CrossRef]

3. Hu, Z.Q.; Zhu, Q.; Xu, J.J.; Zhang, X. Effect of bactericides on control of acidification pollution and spontaneous combustion of coal gangue dumps in China and its mechanism. Sustainability 2020, 12, 6697. [CrossRef]

4. Sun, Y.Q.; Xiao, K.; Wang, X.D.; Lv, Z.H.; Mao, M. Evaluating the distribution and potential ecological risks of heavy metal in coal gangue. Environ. Sci. Pollut. Res. 2021, 28, 18604-18615. [CrossRef] [PubMed]

5. Guo, Y.; Lv, H.; Xi, Y.; Cheng, $\mathrm{F}$. $\mathrm{AlCl}_{3} \cdot 6 \mathrm{H}_{2} \mathrm{O}$ recovery from the acid leaching liquor of coal gangue by using concentrated hydrochloric inpouring. Sep. Purif. Technol. 2015, 151, 177-183. [CrossRef]

6. Xiao, J.; Li, F.C.; Zhong, Q.F.; Bao, H.G.; Wang, B.J.; Huang, J.D.; Zhang, Y.B. Separation of aluminum and silica from coal gangue by elevated temperature acid leaching for the preparation of alumina and SiC. Hydrometallurgy 2015, 155, 118-124. [CrossRef]

7. Zhang, W.C.; Honaker, R. Characterization and recovery of rare earth elements and other critical metals (Co, Cr, Li, Mn, Sr, and V) from the calcination products of a coal refuse sample. Fuel 2020, 267, 117236. [CrossRef]

8. Chen, B.; He, H.; Tan, T.; Lai, D.Q.; Luo, H.F.; Tao, X.X. Liberation characteristics of iron manganese and chromium fraction in coal gangue during Acidithiobacillus ferrooxidans bioleaching process. Chin. J. Environ. Eng. 2017, 11, 4405-4410. (In Chinese) [CrossRef]

9. Mei, J.; He, H.; Hong, F.F.; Leng, Y.W.; Zhao, Y.D.; Zheng, L.; Ma, C.Y.; Tao, X.X. Microbial community structures and sulfur speciation characteristics in soil sample around the Xiang-tan Liejiaqiao coal gangue dump, Hunan province in south of China. Energy Sources Part A Recovery Util. Environ. Eff. 2019, 43, 2256-2266. [CrossRef]

10. Nicomrat, D. Characteristics of cultivated sulfur oxidizing bacteria community isolated from coal mine treatment plant in $\mathrm{H}_{2} \mathrm{~S}$ removal. Appl. Mech. Mater. 2016, 4215, 127-130. [CrossRef]

11. Aytar, P.; Kay, C.M.; Mutlu, M.B.; Cabuk, A. Coal desulfurization with Acidithiobacillus ferrivorans, from Balya acidic mine drainage. Energy Fuels 2013, 27, 3090-3098. [CrossRef]

12. Mishra, S.; Panda, P.P.; Pradhan, N.; Satapathy, D.; Subudhi, U. Effect of native bacteria Sinomonas flava 1C and Acidithiobacillus ferrooxidans on desulphurization of Meghalaya coal and its combustion properties. Fuel 2014, 17, 415-421. [CrossRef]

13. Liu, F.W.; Lei, Y.S.; Shi, J.; Zhou, L.X.; Wu, Z.H.; Dong, Y.; Bi, W.L. Effect of microbial nutrients supply on coal bio-desulfurization. J. Hazard. Mater. 2019, 384, 121324. [CrossRef] [PubMed]

14. Sarswat, P.K.; Leake, M.; Allen, L.; Free, M.L.; Hu, X.; Kim, D.; Noble, A.; Luttrell, G.H. Efficient recovery of rare earth elements from coal-based resources: A bioleaching approach. Mater. Today Chem. 2020, 16, 100246. [CrossRef]

15. Deng, S.; Gu, G.H.; Wu, Z.T.; Xu, X.Y. Bioleaching of arsenopyrite by mixed cultures of iron-oxidizing and sulfur-oxidizing microorganisms. Chemosphere 2017, 185, 403-411. [CrossRef] [PubMed]

16. Zhang, R.Y.; Duan, J.Z.; Xu, D.K.; Xia, J.L.; Munoz, J.A.; Sand, W. Editorial: Bioleaching and biocorrosion: Advances in interfacial processes. Front. Microbiol. 2021, 12, 653029. [CrossRef] [PubMed]

17. Irrgang, N.; Monneron, B.; Mockel, R.; Schlomann, M.; Hock, M. Economic feasibility of the co-production of indium from zinc sulfide using bioleaching extraction in Germany. Hydrometallurgy 2021, 200, 105566. [CrossRef]

18. He, H.; Han, Y.T.; Shi, K.Y.; Hong, F.F.; Zhu, H.W.; Leng, Y.W.; Tao, X.X.; Zheng, L.; Ma, C.Y.; Zhao, Y.D. Variation of sulfur speciation of coal gangue leaching by acidophilic ferrous/sulfur oxidizing microbes. J. China Coal Soc. 2017, 42, 1304-1310. (In Chinese) [CrossRef]

19. Liang, C.L.; Xia, J.L.; Nie, Z.Y.; Yi, Y.; Ma, C.Y. Effect of sodium chloride on sulfur speciation of chalcopyrite bioleached by the extreme thermophile Acidianus manzaensis. Bioresour. Technol. 2012, 110, 462-467. [CrossRef]

20. Zhang, R.Y.; Wei, D.Z.; Shen, Y.B.; Liu, W.G.; Lu, T.; Han, C. Catalytic effect of polyethylene glycol on sulfur oxidation in chalcopyrite bioleaching by Acidithiobacillus ferrooxidans. Miner. Eng. 2016, 95, 74-78. [CrossRef]

21. Zhang, D.R.; Xia, J.L.; Nie, Z.Y.; Chen, H.R.; Liu, H.C.; Deng, Y.; Zhao, Y.D.; Zhang, L.L.; Wen, W.; Yang, H.Y. Mechanism by which ferric iron promotes the bioleaching of arsenopyrite by the moderate thermophile Sulfobacillus thermosulfidooxidans. Process Biochem. 2019, 81, 11-21. [CrossRef]

22. Zhao, S.M.; He, H.; Yu, Z.Q.; Huang, G.H.; Leng, Y.W.; Tao, X.X. Factor screening and condition optimization of desulfurization of coal gangue with Acidithiobacillus ferrooxidans. Chin. J. Environ. Eng. 2015, 9, 4585-4590. (In Chinese)

23. She, C.J.; Tang, J.L.; He, H.; Zhang, M.; Tong, L.; Tang, J.; Tao, X.X. Combining Desulfuromonas alkenivorans S-7 with rice husk to treat acid heavy metal wastewater. J. China Coal Soc. 2019, 44, 2851-2858. (In Chinese) [CrossRef]

24. Grey, R.G.; Saunders, P.J. Atomic Absorption Spectrometer. WO2003014678, 6 August 2002. 
25. Liu, L.; Li, X.H.; Zhou, Z.M.; Lin, Y.; Lu, Y.Y. Effects of Simulated Acid Rain on Soil Acidification and Base cations Release of Four Types of Typical Soils from the Three Gorges Reservoir Region. J. Chongqing Univ. (Nat. Sci. Ed.) 2007, 8, 63-69. (In Chinese) [CrossRef]

26. Qiu, Q.Y.; Wu, J.P.; Liang, G.H.; Liu, J.X.; Chu, G.W.; Zhou, G.Y.; Zhang, D.Q. Effects of simulated acid rain on soil and soil solution chemistry in a monsoon evergreen broad-leaved forest in southern China. Environ. Monit. Assess. 2015, 187, 272. [CrossRef] [PubMed]

27. Karltun, E. Modelling $\mathrm{SO}_{4}{ }^{2-}$ surface complexation on variable charge minerals: $\mathrm{I}^{-\mathrm{H}^{+}}$and $\mathrm{SO}_{4}{ }^{2-}$ exchange under different solution conditions. Eur. J. Soil Sci. 2008, 48, 483-491. [CrossRef]

28. Li, J.H.; Jia, C.J.; Lu, Y.; Tang, S.F.; Shim, H. Multivariate analysis of heavy metal leaching from urban soils following simulated acid rain. Microchem. J. 2015, 122, 89-95. [CrossRef]

29. Acharya, B.S.; Kharel, G. Acid mine drainage from coal mining in the United States-An overview. J. Hydrol. 2020, $588,125061$. [CrossRef]

30. Dutta, M.; Islam, N.; Rabha, S.; Narzary, B.; Bordoloi, M.; Saikia, D.; Silva, L.F.; Saikia, B.K. Acid mine drainage in an Indian high-sulfur coal mining area: Cytotoxicity assay and remediation study. J. Hazard. Mater. 2020, 389, 121851. [CrossRef] [PubMed]

31. Cao, Y.Q.; Zhang, S.S.; Liu, H.H.; Liu, W. Leaching characteristics of heavy metals in coal gangue in both dynamic leaching and static immersion. J. Hebei Univ. Eng. 2010, 10, 76-80. [CrossRef]

32. Zhang, H.J.; Ouyang, S. Release characteristics of heavy metals from coal gangue under simulation leaching conditions. Energy Explor. Exploit. 2014, 32, 413-422. [CrossRef]

33. Rohwerder, T.; Gehrke, T.; Kinzler, K.; Sand, W. Bioleaching review part A. Appl. Microbiol. Biotechnol. 2003, 63, 239-248. [CrossRef]

34. Kaksonen, A.H.; Lakaniemi, A.M.; Tuovinen, O.H. Acid and ferric sulfate bioleaching of uranium ores: A review. J. Clean. Prod. 2020, 264, 121586. [CrossRef]

35. Wang, C.; Lv, C.; Bai, Z.; Deng, J.; Kang, F.; Xiao, Y.; Shu, C.M. Synergistic acceleration effect of coal spontaneous combustion caused by moisture and associated pyrite. Fuel 2021, 304, 121458. [CrossRef]

36. Xue, Q.; Lu, H.J.; Zhao, Y.; Liu, L. The metal ions release and microstructure of coal gangue corroded by acid-based chemical solution. Environ. Earth Sci. 2014, 71, 3235-3244. [CrossRef]

37. Tripathy, S.; Bhattacharyya, P.; Mohapatra, R.; Som, A.; Chowdhury, D. Influence of different fractions of heavy metals on microbial ecophysiological indicators and enzyme activities in century old municipal solid waste amended soil. Ecol. Eng. 2014, 70, 25-34. [CrossRef]

38. He, H.; Hong, F.F.; Tao, X.X.; Huang, G.H.; Leng, Y.W.; Shao, J.F.; Zhao, Y.D. A study on soil basic characteristics, main microbial flora and typical metal fraction surrounding coal gangue dump in Xiangtan Hunan Province, south of China. Environ. Earth Sci. 2016, 75, 488. [CrossRef]

39. Lizama, H.M.; Suzuki, I. Bacterial leaching of a sulfide ore by Thiobacillus ferrooxidans and Thiobacillus thiooxidans: I. shake flask studies. Biotechnol. Bioeng. 2010, 32, 110-116. [CrossRef] [PubMed]

40. Xu, G.G.; Gu, S.C.; Wang, X.D.; Wang, H.; Zhu, S.B. Grouting to prevent sulfate corrosion on coal mine shaft. KSCE J. Civ. Eng. 2021, 7, 1-11. [CrossRef]

41. Leemann, A.; Loser, R. Analysis of concrete in a vertical ventilation shaft exposed to sulfate-containing groundwater for 45 years. Cem. Concr. Compos. 2010, 33, 74-83. [CrossRef]

42. Nguyen, T.H.; Lee, M.S. A review on the recovery of titanium dioxide from ilmenite ores by direct leaching technologies. Miner. Process. Extr. Metall. Rev. 2019, 40, 231-247. [CrossRef]

43. Parker, A.; Klauber, C.; Kougianos, A. An X-ray photoelectron spectroscopy study of the mechanism of oxidative dissolution of chalcopyrite. Hydrometallurgy 2003, 71, 265-276. [CrossRef]

44. Moulder, J.F.; Chastain, J.; King, R.C. Handbook of X-ray photoelectron spectroscopy: A reference book of standard spectra for identification and interpretation of XPS data. Chem. Phys. Lett. 1992, 220, 7-10. [CrossRef]

45. Li, P.S.; Hu, Y.; Yu, W.; Yue, Y.N.; Xu, Q.; Hu, S.; Hu, N.S.; Yang, J. Investigation of sulfur forms and transformation during the co-combustion of sewage sludge and coal using X-ray photoelectron spectroscopy. J. Hazard. Mater. 2009, 167, 1126-1132. [CrossRef] [PubMed]

46. Liao, R.; Yu, S.C.; Wu, B.Q.; Zhao, C.X.; Lin, H.; Hong, M.X.; Wu, H.Y.; Yang, C.R.; Zhang, Y.S.; Xie, J.P.; et al. Sulfide mineral bioleaching: Understanding of microbe-chemistry assisted hydrometallurgy technology and acid mine drainage environment protection. J. Cent. South Univ. 2020, 27, 1367-1372. [CrossRef]

47. Bellenberg, S.; Huynh, D.; Poetsch, A.; Sand, W.; Vera, M. Proteomics reveal enhanced oxidative stress responses and metabolic adaptation in Acidithiobacillus ferrooxidans biofilm cells on pyrite. Front. Microbiol. 2019, 10, 592. [CrossRef] [PubMed]

48. Wu, B.; Shang, H.; Wen, J.K. Research of column microbial desulfurization of high sulfur coal. In Proceedings of the 4th International Conference on Mechanical Materials and Manufacturing Engineering, Wuhan, China, 15-16 October 2016; Atlantis Press: Paris, France, 2016; Volume 79, pp. 466-469. [CrossRef] 